\title{
Physisporinus rivulosus, an interesting polypore species
}

\author{
HEIKKI KOTIRANTA
}

\begin{abstract}
KOTIRANTA, H. 1985: Physisporinus rivulosus, an interesting polypore species. Karstenia 25: 66-69.

The polypore Physisporinus rivulosus (Berk. \& Curt.) Ryv. is reported as new to Finland. It is better known as Poria albipellucida Baxter and widely distributed in North America. The Finnish specimen is from Pinus sylvestris L. Though P. rivulosus is the only known species of Physisporinus Karst. with clamp connections, it otherwise fits well with that genus. The macroscopical and microscopical characteristics of $P$. rivulosus are described and illustrated, and the taxonomy is briefly discussed.
\end{abstract}

Heikki Kotiranta, Department of Botany, University of Helsinki, Unioninkatu 44, SF00170 Helsinki, Finland

\begin{abstract}
Introduction
Physisporinus rivulosus is widely distributed in North and Central America (Lowe 1966), but records from other parts of the world are few. In external appearance it greatly resembles Skeletocutis subincarnata (Peck) Keller and was provisionally determined as that species in the field. However, microscopically it proved to be a monomitic, clamped species with subglobose spores and without the rosethorn-shaped crystals characteristic of the genus Skeletocutis Kotl. \& Pouz. (Keller 1979, David 1982, Kotiranta 1984).

Jülich (1984), Ryvarden $(1976,1978)$ and Ryvarden \& Johansen (1980) do not mention any taxon with this combination of characters, but Lowe's (1966) drawings and description of Poria rivulosa (Berk. \& Curt.) Cooke showed many similarities to my specimen, and David's (1972) paper finally confirmed the identity of the species.
\end{abstract}

Physisporinus rivulosus (Berk. \& Curt.) Ryvarden, Mycotaxon 20: 353. 1984.

Polyporus rivulosus (Berk. \& Curt., J. Linn. Soc. 10: 318. 1868. Typus: Cuba, Monte Verde, on dead Polypori, C. Wright 154 (S, 'Type', evidently isotype; examined). - Poria rivulosa (Berk. \& Curt.) Cooke, Grevillea 14: 109. 1886. Rigidoporus rivulosus (Berk. \& Curt.) David, Bull. Soc. Mycol. France 87: 418. 1972, nom. inval. (Art. 33).

Poria albipellucida Baxter, Mich. Acad. Sci. Arts Lett. Papers 23: 291. 1938. Typus: Canada, British Columbia, Vancouver, on Thuja plicata, D.V. Baxter 23.VIII.1935 (MICH, holotype); examined.

Fruit body annual, resupinate, $13 \times 5 \mathrm{~cm}$, composed of small roundish pieces which grow together, pure white when fresh, light cream or ochre with a few dark brown flecks when dry, in part contracting, sterile margin narrow (less than $1 \mathrm{~mm}$ ), white also in dry condition. Subiculum resinous, hard, tubes brittle when dry.
Pores roundish to angular, thin-walled, 4-6 (-7) per $\mathrm{mm}$. Tubes up to $1.3 \mathrm{~mm}$ long, subiculum up to $0.2 \mathrm{~mm}$ thick, in part almost lacking.

Hyphal system monomitic. Subicular hyphae parallel to each other and to the substrate, near pore bottom tightly intertwined, branched, clamped, 2-5 $\mu \mathrm{m}$ wide, fairly thick-walled. In sterile margin $2-3.5$ $\mu \mathrm{m}$ wide, thin-walled, very often simple-septate and with crystals. Contents mainly staining $\mathrm{CB}+$ (for the reactions see Niemelä 1985). Young subiculum with big crystalline clusters. Tramal hyphae $1.5-2.5(-3)$ $\mu \mathrm{m}$ wide, richly branched, intertwined, not very thinwalled. On some hyphae in upper tube almost invisible resinous 'fur'. This resinous matter (in type, S) gives the old tubes a hard consistency and brown colour. In dissepiment edge the hyphae more parallel, slightly wider $(3 \mu \mathrm{m})$, thin-walled, with or without crystals. Subicular and tramal hyphae CRB lilac. Hymenium composed of clavate, sometimes slightly constricted basidia $(15-24 \times 6-7 \mu \mathrm{m})$ with four thin sterigmata (3-4 $\mu \mathrm{m}$ long) and of very numerous bottle-shaped, thin-walled cystidioles $(14-25 \times 3.5-$ $6 \mu \mathrm{m})$ with narrow apical tips. Both basidia and cystidioles basally clamped and filled with clearly visible, variable, refractive droplets. The contents of basidia and cystidioles $\mathrm{CB}+$. Spores subglobose, hyaline, (4-) $4.5-5(-5.1) \times(3.5-) 3.8-4(-4.8)$ $\mu \mathrm{m}$, with one prominent droplet, thin-walled, IKI-, $\mathrm{CB}$-(contents blue).

Specimens examined

Canada. British Columbia: Vancouver, Tsuga heterophylla, 13.IX.1933 Baxter (MICH); Thuja plicata, 23.VIII.1935 Baxter (MICH, holotype of Poria albipellucida); T. heterophylla, 13.IX.1935 Baxter (MICH); Vancouver, Stanley park, on much rotted coniferous log, 8.III.1932 Mounce (MICH). Cuba. See type of Polyporus rivulosus.

Finland. Pohjois-Häme: Saarijärvi, Pyhä-Häkki National Park, corticated, strongly decayed Pinus sylvestris on ground in dry pine - Calluna vulgaris heath, Grid $27^{\circ} \mathrm{E}$ 697:42; 

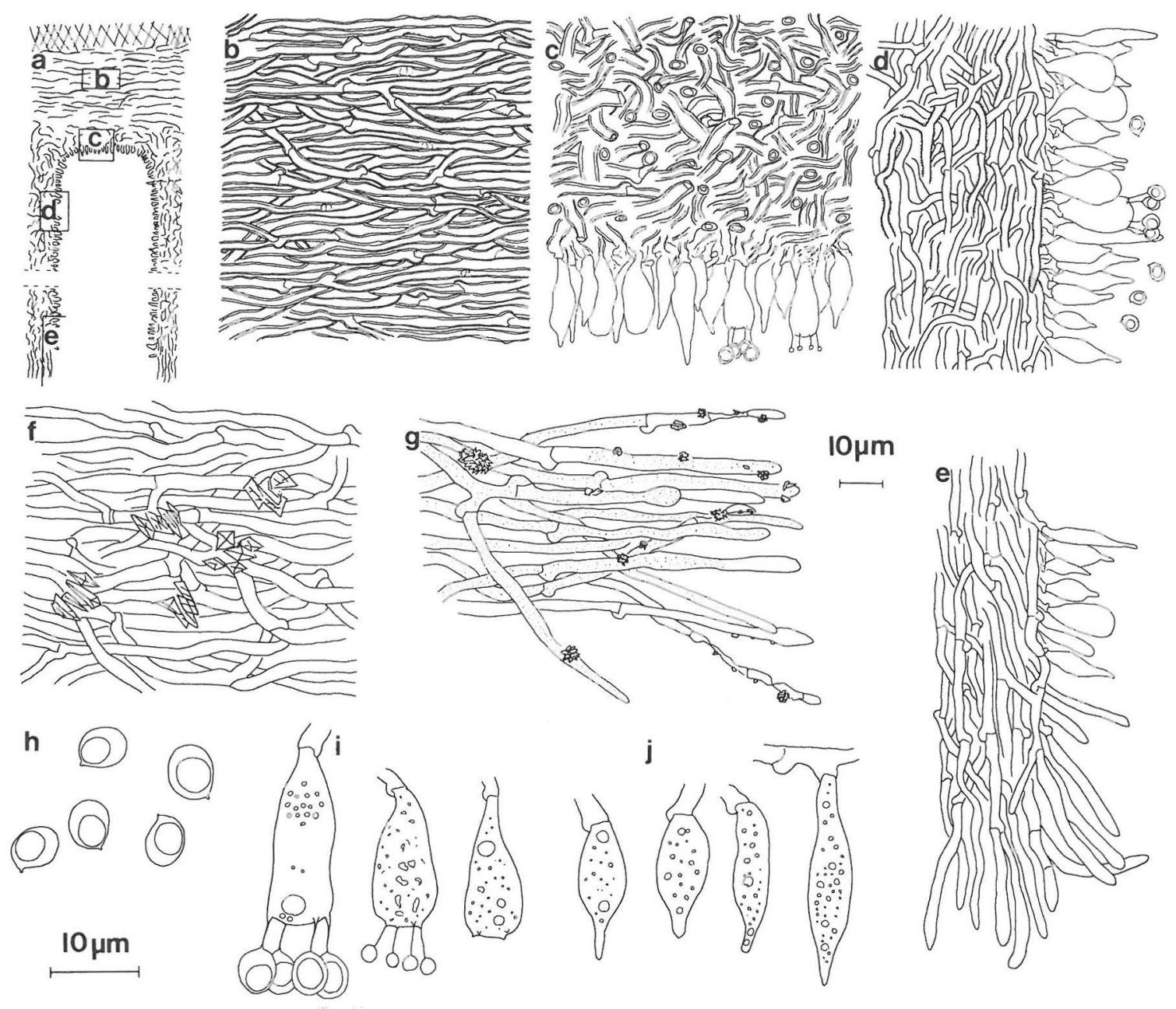

Fig. 1. Physisporinus rivulosus. a) section through fruit body, b) subiculum, c) tube bottom, d) upper tube, e) young dissepiment edge, f) young subiculum with crystals, g) sterile margin, h) spores, i) basidia, j) cystidioles (Kotiranta 5420).

4.IX.1984 Kotiranta 5420 (H, Hb. Kotiranta). U.S.A. California: Prairie Creek Park, charred Sequoia sempervirens, 28.XI.1937 Baxter (MICH); Trinidad, burned S. sempervirens, 3.XII.1956 Smith 56250 (MICH), burned $S$. sempervirens, 6.XII.1956 Smith 56396 (MICH). Idaho: Deception Creek, Coeur d'Alene National Forest, conifer, $900 \mathrm{~m}, 18 . \mathrm{IX} .1956$ Lowe 6987 \& Gilbertson (MICH); Priest River, Pinus monticola, IX.1915 Weir (MICH); Washington: Clallam Co., Hot Springs, Olympic National Park, T. heterophylla 12.IX.1936 Baxter (MICH, paratype of Poria albipellucida); Olympic Peninsula, Queets River, on charred conifer, 90 m, 3.IX.1957 Lowe 8136, Gilbertson \& Griffin (MICH); Verlot, T. heterophylla, 5.X.1937 Englerth (MICH).

[Addendum: Finland. Uusimaa: Helsinki, Vanhakaupunki, Annala, on thick, decorticated, strongly decayed trunk of Pinus sylvestris, beside a camp fire place, Grid $27^{\circ} \mathrm{E}$ 6679:387, 11.IX.1985 Saarenoksa 39585, 6.X.1985 Saarenoksa $51485(\mathrm{H}, \mathrm{Hb}$. Kotiranta, Hb. Niemelä). - This is the second find of $P$. rivulosus in Finland. It was collected after this paper already was in press and is therefore not treated in detail. It is macroscopically as well as microscopically very similar to my specimen. However, there are some differences in the abundance of clamps. The clamps are few, especially in the trama, and the hyphae are mostly simple-septate, thus resembling those seen in other species of Physisporinus. I am grateful to Mr Reima Saarenoksa, who gave these new collections at my disposal.]

\section{Distribution and ecology}

$P$. rivulosus is already known from Cuba (Berkeley \& Curtis 1868), Canada (Buckland 1946), the United States (Baxter 1938, Cooke 1942, Lowe 1966) and France (David 1972). The first record in Fennoscandia is from Central Finland, northern Lake District (see Niemelä 1982).

Finland lies almost wholly in the Boreal zone (Hämet-Ahti 1981) and the new locality in the PyhäHäkki National Park is situated in the transitional 


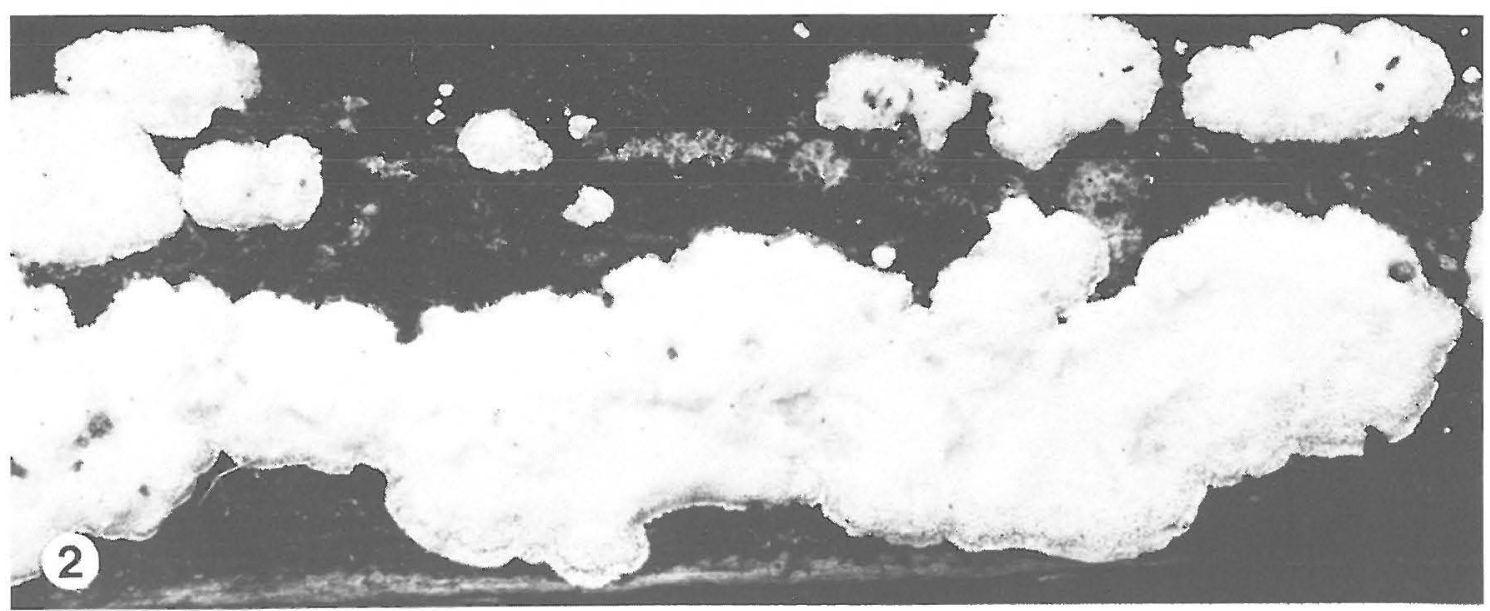

Figs. 2-3. Physisporinus rivulosus. Note the pure white, narrow, sterile margin, and partly contracting hymenophore. - 2: Fresh specimen (Saarenoksa 39585, X 1.5). - 3: Dried specimen (Kotiranta 5420, X 3).

area between the Southern and Middle boreal subzones (for these subzones see the map in Niemelä 1982). The forests in this area are composed of spruce, pine, birch and aspen trees. The Pyhä-Häkki National Park is mainly in a virgin state and Picea abies is dominant, being the climax tree. In dry sites, however, Pinus sylvestris is dominant.

The Finnish specimen of Physisporinus rivulosus was collected on corticated, strongly decayed, fallen Pinus sylvestris; no other polypore species were noted on the same trunk. The locality is dry Calluna vulgaris - Pinus sylvestris woodland. The other European collections, made in France, are also from pine (David 1972). Baxter (1938), Cooke (1942), Kimmey and Lightle (1955) and Kimmey (1958) report several additional hosts from North America (Tsuga heterophylla, Thuja plicata, Pseudotsuga menziesii, Sequoia sempervirens, Alnus oregana).

The rot in the Finnish material is more or less fibrous, light brown, and seems to be a white-rot. The white mycelial flecks between the laminae of decayed wood mentioned by Buckland (1946) and Kimmey and Lightle (1955) are clearly seen in the Finnish collection. According to Buckland (1946), P. rivulosus causes white ring rot (white-rot; Nobles 1948) and is one of the main heart-rotting fungi of living western red cedars in British Columbia and also a very significant decomposer of redwood in the western United States (Kimmey \& Lightle 1955, Kimmey 1958).

Four of the North American collections examined by me are from charred wood, and two of these are mixed samples (Baxter 28.XI.1937 and Smith 56250). In both cases the other polypore species is Oligoporus sericeomollis (Rom.) Pouz., in Finland found mostly on charred pine stumps.

There is also one collection from Alaska: Wrangell,

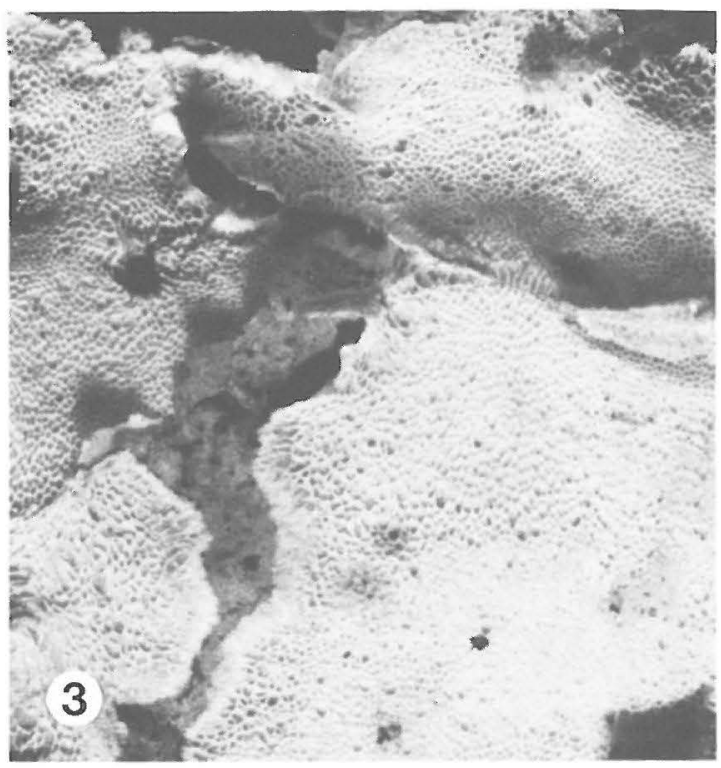

which was collected on 9 September 1935 and determined by D.V. Baxter as Poria albipellucida (= Physisporinus rivulosus). This collection is provided with Baxter's notes: 'Snow white when fresh' and 'Badly eaten by worms and so not typical'. The specimen is in fact eaten by nematodes, but in my opinion it does not represent $P$. rivulosus. It is much softer, the border is rhizomorphic and the hyphae are wider and thicker-walled than in $P$. rivulosus. The hymenium has been eaten and is also infected by moulds, so that I could not find any basidiospores.

\section{Discussion}

The systematic position of $P$. rivulosus has long been unclear. David's (1972) proposed inclusion of $P$. rivulosus in Rigidoporus has not generally been accepted (and is nomenclaturally invalid) and Mme A. David (in litt.) herself was not entirely satisfied with the decision. 
Jülich (1984) re-established the genus Physisporinus Karst., which had long been neglected and regarded as synonymous with Rigidoporus. The type species of Physisporinus is Poria vitrea Pers.: Fr., which is annual, resupinate, soft when fresh, contracting in dry condition, has cystidioles, crystals on the hyphae and subglobose spores. These characters all belong to $P$.rivulosus as well, and the present species also closely agrees with the other Physisporinus species in its general appearance.

It seems that Physisporinus should be regarded as a genus which includes both species with simple septa and species with clamp connections. In this broader sense the genus is characterized by species with annual fruit bodies, a monomitic hyphal system, cystidioles, simple-septate or clamped hyphae and subglobose spores. This solution would separate Poria vitrea (incl. Polyporus undatus Pers.) from the species of the genus Rigidoporus Murr. In fact, Physisporinus differs from the corky, perennial species of Rigidoporus s.str., e.g. Rigidoporus nigrescens (Bres.) Donk and R. ulmarius (Sow.: Fr.) Imazeki, in being soft and annual.

The species of Oxyporus Donk are either annual or perennial, corky and simple-septate, having spores that are broadly ellipsoid to subglobose. These characters so closely resemble those seen in Rigidoporus s.str. that it is not surprising that these two genera are considered congeneric by some authors (Pouzar 1966, Kotlaba 1984).

Though $P$. rivulosus is the only Physisporinus species with clamp connections, I agree with Ryvarden's (1984) inclusion of Polyporus rivulosus Berk. \& Curt. (Poria rivulosa (Berk. \& Curt.) Cooke) in Physisporinus.

Acknowledgements. I want to thank my teacher Tuomo Niemelä (Helsinki) for many advise and discussions as well as Mme Alix David (Lyon). My thanks are also due to the curators of herbaria cited which have kindly sent me material on loan.

The work was supported by grants from the Emil Aaltonen foundation and the fund Suomen Kulttuurirahasto.

The English of this paper was revised by Mrs Anna A. Damström, M.A.

\section{References}

Baxter, D.V. 1938: Some resupinate polypores from the region of the Great Lakes 9. - Papers Mich. Acad. Sci. Arts Lett. 23: 285-305.
Berkeley, M.J. \& Curtis, M.A. 1868: Fungi Cubenses (Hymenomycetes). - J. Linn. Soc. 10: 280-342.

Buckland, D.C. 1946: Investigations of decay in western red cedar in British Columbia. - Can. J. Res., C 24: 158181.

Cooke, W.B. 1942: Resupinate pore fungi in Oregon. Amer. Midl. Nat. 27: 677-695.

David, A. 1972: Caractères myceliens de Rigidoporus rivulosus (Berk. et Curt.) comb. nov., espèce nouvelle pour l'Europe. - Bull. Soc. Mycol. France 87: 415419 .

- 1982: Étude monographique du genre Skeletocutis (Polyporaceae). - Naturaliste Canadien 109: 235-272.

Hämet-Ahti, L. 1981: The boreal zone and its biotic subdivision. - Fennia 159(1): 69-75.

Jülich, W. 1984: Die Nichtblätterpilze, Gallertpilze und Bauchpilze (Aphyllophorales, Heterobasidiomycetes, Gastromycetes). - In: Gams, H., Kleine Kryptogamenflora 2b(1): Basidiomyceten 1. - $626 \mathrm{pp}$. Stuttgart \& New York

Keller, J. 1979: Ultrastructure des hyphes incrustées dans le genre Skeletocutis. - Persoonia 10: 347-355.

Kimmey, J.W. 1958: The heart rots of redwood. - U.S Dept. Agric. Forest Pest Leaflet 25: 1-7.

Kimmey, J.W. \& Lightle, P.C. 1955: Fungi associated with cull in redwood. - Forest Sci. 1: 104-110.

Kotiranta, H. 1984: Skeletocutis jelicii: a new member of the Finnish polypore flora. - Karstenia 24: 73-76

Kotlaba, F. 1984: Zeměpisné rozšíření a ekologie chorošu (Polyporales s.l.) v Ceskoslovenska - $194 \mathrm{pp}$. Praha.

Kotlaba, F. 1984: Zeměpisné rozšiřeni a ekologie chorošu (Polyporales s.1.) v Ceskoslovensku. - 194 pp. Praha.

Lowe, J.L. 1966: Polyporaceae of North America. The genus Poria. - State Univ. Coll. Forest Syracuse Univ. Techn. Publ. 90: 1-183.

Niemelä, T. 1982: Polypore survey of Finland 1. Introduction. - Karstenia 22: 21-26.

- 1985: On Fennoscandian polypores 9. Gelatoporia n.gen. and Tyromyces canadensis, plus notes on Skeletocutis and Antrodia. - Karstenia 25: 21-40.

Nobles, M.K. 1948: Studies in forest pathology 5 . Identification of cultures of wood-rotting fungi. - Can. J. Res., C 26: $281-431$.

Pouzar, Z. 1966: Studies in the taxonomy of the Polypores 2. - Fol. Geobot. Phytotax. Bohemoslovac. 1: 356-375.

Ryvarden, L. 1976: The Polyporaceae of North Europe 1. Albatrellus to Incrustoporia. - Pp. 1-214. Oslo.

- 1978: The Polyporaceae of North Europe 2. Inonotus to Tyromyces. - Pp. 219-507. Oslo.

- 1984: Type studies in the Polyporaceae 16. Species described by J.M. Berkeley, either alone or with other mycologists from 1856 to 1886 . - Mycotaxon 20: 329363.

Ryvarden, L. \& Johansen, I. 1980: A preliminary polypore flora of East Africa. - 636 pp. Oslo. 